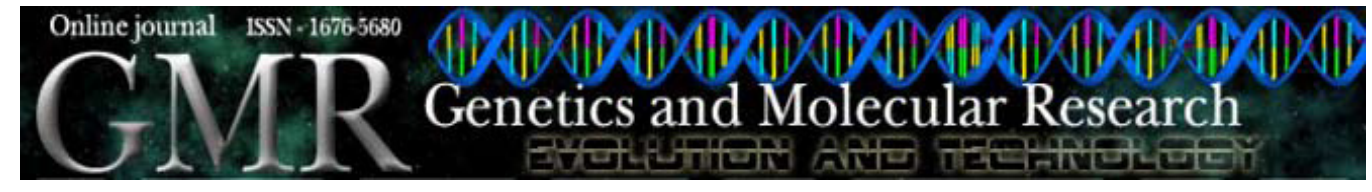

\title{
Bionomics and sociological aspects of Euglossa fimbriata (Apidae, Euglossini)
}

\author{
S.C. Augusto ${ }^{1}$ and C.A. Garófalo ${ }^{2}$ \\ ${ }^{1}$ Instituto de Biologia, Universidade Federal de Uberlândia, \\ Uberlândia, MG, Brasil \\ ${ }^{2}$ Departamento de Biologia, Faculdade de Filosofia, \\ Ciências e Letras de Ribeirão Preto, USP, Ribeirão Preto, SP, Brasil \\ Corresponding author: C.A. Garófalo \\ E-mail: garofalo@ffclrp.usp.br
}

Genet. Mol. Res. 8 (2): 525-538 (2009)

Received December 12, 2008

Accepted January 26, 2009

Published May 12, 2009

\begin{abstract}
The nesting biology and the social structure of Euglossa fimbriata were studied based on two original nests found on the campus of the University of São Paulo, Ribeirão Preto, Brazil. Nest 1 contained two inseminated females, 39 sealed cells, one cell being provisioned, and six old and empty cells. Nest 2 contained three inseminated females, 45 sealed cells, one cell being provisioned, and 27 old and empty cells. The cells of nest 1 were distributed into three clusters from which three new nests were set up in the laboratory and maintained in observation boxes from August 1993 to March 1994 in order to study the behaviors performed by the bees. The males left the nest immediately after emergence and did not return. Some females left the nest within a few days of eclosing, and others stayed in their original nests and began to reactivate them. The E. fimbriata colonies were small, with semi-social and eusocial organization. In these colonies one female becomes the dominant female, usually the oldest female, and the others behave as subordinate females. The subordinate females build their cells, provision and oviposit in them, while the dominant female becomes the major guard bee, and oviposits in cells oviposited in by subordinate females. Oviposition by the dominant female is always preceded by oophagy. Irrespective of the behavior displayed, all the females that we dissected had been inseminated. The
\end{abstract}


behavior displayed by the dominant female is characteristic of brood parasitism and fits the parental parasitism hypothesis developed as an alternative pathway by which insect sociality could have arisen.

Key words: Euglossa; Nesting behavior; Brood parasitism; Social structure; Social evolution

\section{INTRODUCTION}

The corbiculate bees are a group of long-tongued bees within the family Apidae and comprise four tribes: the honey bees (Apini), the stingless bees (Meliponini), the bumble bees (Bombini), and the orchid bees (Euglossini). Of the four, only orchid bees exhibit various levels of sociality, including communal, semisocial and primitively social (Zucchi et al., 1969a; Garófalo, 1985; Pereira-Martins and Kerr, 1991; Santos and Garófalo, 1994; Ramírez-Arriaga et al., 1996; Garófalo et al., 1998; Cameron and Ramírez, 2001; Soucy et al., 2003; Augusto and Garófalo, 2004) besides solitary species (Dressler, 1982; Cameron, 2004). Although this tribe may provide insights about the evolution of social behavior in corbiculate bees, there is little information available about nesting biology from this group. Euglossa is the largest genus of the Euglossini, with 111 species (Parra-H et al., 2006); detailed studies on the nesting behavior have been made of only five species, Euglossa cordata (Garófalo, 1985, 1992; Augusto and Garófalo, 1994), Euglossa atroveneta (Ramírez-Arriaga et al., 1996), Euglossa annectans (Garófalo et al., 1998), Euglossa hyacinthina (Soucy et al., 2003), and Euglossa townsendi (Augusto and Garófalo, 2004). Euglossa annectans and E. hyacinthina are considered to be communal species while $E$. cordata, E. atroveneta and $E$. townsendi may present small colonies with semi-social and eusocial organization. In colonies of E. cordata and E. atroveneta, one female becomes the dominant female and the others behave as subordinate females (Garófalo, 1985; RamírezArriaga et al., 1996). The subordinate females provision and oviposit cells, while the dominant female acts as a guard, rarely leaves the nest and oviposits in cells provisioned and oviposited in by subordinate females. Oviposition by the dominant female is always preceded by oophagy and usually occurs immediately after the subordinate female has laid an egg and sealed the cell. In $E$. cordata, task allocation is based on age, with the oldest female becoming the dominant one; task reversal occurs only when a subordinate female replaces the dominant female (Garófalo, 1985; Garófalo CA, unpublished data). In E. townsendi, besides the oldest female, other females may also behave as egg-laying females, while the others behave as forager/egg-laying females ( $\mathrm{Au}$ gusto and Garófalo, 2004). The presence of more than one egg-laying female in the nest leads to multiple egg replacements in the same cell. Oviposition by one egg-laying female is always preceded by oophagy. Agonistic interactions among the females have not been observed in $E$. townsendi, though it occurs in E. cordata between dominant and subordinate females. Augusto and Garófalo (2004) concluded that E. cordata and E. townsendi have bionomical traits that resemble the conditions suggested as precursors of the origin of eusociality in Apinae.

Euglossa (Euglossa) fimbriata Rebelo \& Moure 1995 has only been recorded in Brazil. Information from males sampled with chemical baits indicates the occurrence of E. fimbriata in the States of Maranhão (Rebêlo and Silva, 1999), Paraná (Sofia and Suzuki, 2004) and in the southeast region of Brazil (Rebêlo, 2001). We studied the nesting behavior and the social structure of nests of E. fimbriata, a species that has nests with associations of females of the same gen- 
eration and/or females of different generations. We analyzed the social structure of this species to determine whether it supports the parental parasitism hypothesis presented by Charnov (1978) and Stubblefield and Charnov (1986) as an alternative pathway for the eusociality of insects.

\section{MATERIAL AND METHODS}

Two nests of E. fimbriata were found on the University of São Paulo campus in Ribeirão Preto, São Paulo, Brazil. Nest 1 (N1) was found on July 29, 1993, in a wooden box (inside dimensions $20.0 \times 20.0 \times 20.0 \mathrm{~cm}$ ) that had been placed in the field to attract Meliponini colonies. The nest was taken to the laboratory one day after it was found and the two females inside were collected. The cells were arranged in three clusters from which three new nests $\left(\mathrm{C}_{1}, \mathrm{C}_{2}\right.$ and $\left.\mathrm{C}_{3}\right)$ were set up in the laboratory. Each cluster was transferred to an observation box that consisted of a wooden box (inside dimensions $14.0 \times 12.5 \times 4.5 \mathrm{~cm}$ ) covered with a glass lid and that had a $10-\mathrm{mm}$ circular entrance hole on one side. After the emergence of a female, the wooden boxes were placed so that the bees could leave the boxes freely through a plastic tube connecting to the outside through a hole in the laboratory wall. Nest 2 (N2) was located on March 29, 1996. This nest had been established inside a hollow concrete block (inside dimensions $9.0 \times 10.5 \times 14.0 \mathrm{~cm})$ within a wall $(4.0 \mathrm{~m}$ long and $0.4 \mathrm{~m}$ high) in front of a small sloping earth bank (1.4 m high). The bees entered a $1.29 \times 1.09-\mathrm{cm}$ hole on one side of the cement block. After some observations were made on foraging activities, the cell clusters and the females present $(\mathrm{N}=3)$ were collected. In the laboratory, the nest was placed in an observation box similar to those utilized for nests $\mathrm{C}_{1}, \mathrm{C}_{2}$ and $\mathrm{C}_{3}$.

Detailed observations on the activities of the bees were only made in nests $\mathrm{C}_{1}, \mathrm{C}_{2}$ and $\mathrm{C}_{3}$, from August 1993 to March 1994. The observations were made through a glass lid covering the wooden box and the activities of cell construction, provisioning, oviposition, and cell sealing were recorded for a total of $568 \mathrm{~h}$. When more than two females shared a nest, they were marked with spots of paint on the scutum to facilitate the identification of each individual. To check for oophagy and egg replacement, multifemale nests were observed for a total of $188 \mathrm{~h}$. These observations were made for periods ranging from $30 \mathrm{~min}$ to $5 \mathrm{~h}$ after a female had finished the provisioning of her cell and had oviposited in it. Other cases of oophagy and egg replacement must have occurred when the nests were not being observed. In order to determine whether or not the females sharing a nest were inseminated, seven females were removed from their nests after they had finished their reproductive activities and dissected.

Each spermatheca was squashed between a slide and a coverslip and examined under a microscope.

Statistical analyses were performed using Statistica 5.0 (StatSoft, Inc.). Throughout the text, data are reported as means \pm standard deviation.

\section{RESULTS}

\section{Nest structure and emergence of imagoes}

Nest 1 contained two inseminated females and 46 cells scattered in three clusters $\left(\mathrm{C}_{1}-\mathrm{C}_{3}\right)$. Cluster $1\left(\mathrm{C}_{1}\right)$ had been built on the floor of the wooden-box and had 14 sealed cells, one was empty and old, and one was being provisioned. Cluster $2\left(\mathrm{C}_{2}\right)$ was attached 
to the wall of wooden-box that contained the nest entrance, and it was about $5.5 \mathrm{~cm}$ above the floor. This cluster had 14 sealed cells, and one empty and old cell. Cluster $3\left(\mathrm{C}_{3}\right)$ was attached to the nest box wall on the right of the wall containing the nest entrance. This cluster was about $12.5 \mathrm{~cm}$ above the floor and it had 11 sealed cells and four old and empty cells. The wooden-box did not have any inner wall coating. Resinous particles had been deposited on the floor of the box. The box entrance was about $1.3 \mathrm{~cm}$ in diameter and it had been constricted by a resinous wall in which there was a small circular hole just large enough for the female to pass. From the 39 sealed cells, two males and eight females emerged from $\mathrm{C}_{1}$, seven males and three females from $\mathrm{C}_{2}$, and four males and three females from $\mathrm{C}_{3}$. Among the 12 remaining cells, individuals emerged when the new nests $\left(\mathrm{C}_{1}, \mathrm{C}_{2}\right.$ and $\left.\mathrm{C}_{3}\right)$ were not being observed, and these individuals did not return to the nests.

Nest 2 contained three inseminated females, 45 capped cells, one being provisioned and, at least, $27 \mathrm{old}$ and empty cells. An orifice $(1.29 \times 1.09 \mathrm{~cm})$ in the wall of the cement brick was utilized as a nest entrance; it had been constricted by the construction of a resinous wall. As with N1, the cavity containing N2 had numerous resinous particles deposited on the floor, and the walls did not have any inner coating. The cells were also distributed in three clusters. Cluster 1 had been built on the floor of the cavity and contained 27 old and empty cells and five sealed cells. Clusters 2 and 3 were attached to the wall of the cement brick containing the nest entrance; cluster 2 had 19 sealed cells and cluster 3 had 21 sealed cells and one being provisioned. Among the 45 sealed cells, seven cells contained dead individuals (three females, two males and two larvae) and 23 cells produced adult bees (16 males and seven females). Among the 15 remaining cells, the sex of individuals was not identified because the emergences occurred when the nest was not being observed.

The cells were made of dark resin and had an elliptical shape. They were built in close contact and they were $11.0-18.9 \mathrm{~mm}($ mean $=15.1 \pm 2.3 \mathrm{~mm} ; \mathrm{N}=21)$ long by 7.7-9.4 mm (mean $=8.8 \pm 0.5 \mathrm{~mm} ; \mathrm{N}=14$ ) in maximum diameter.

The bees normally emerged in the morning. All emerging bees left their cells by chewing an arc around the apical portion of the cell until the cap could be pushed open. Soon after emergence, both males and females cleaned themselves and then left the nest. The males never returned to the nests. The females frequently remained in the nests and participated in their reactivation.

\section{Reactivation processes and behaviors performed by females}

A reactivation process $(=\mathrm{R})$ is initiated when a newly emerged female remains in its natal nest and begins to work in it. The duration of the reactivation process (from the beginning of foraging for resin until the last oviposition by reactivating females, $\mathrm{N}=12$ ) ranged from 21 to 97 days. After finishing a reactivation, the females remained in the nest without performing field activities. This period of inactivity ranged from 21 to 81 days $(\mathrm{N}=6)$ and was interrupted when a new reactivation was initiated. In three cases, a new reactivation was initiated before the previous one had ended.

The number of reactivations observed in nests $C_{1}, C_{2}$, and $C_{3}$, were 4,6 , and 2 , respectively. The reactivation processes were classified into 3 types: I - reactivation by a single female; II - reactivation by more than one female in the absence of females that had participated in the previous reactivation; III - reactivation by one female, or more than one female, in the presence of a female that had participated in the previous reactivation. 
In type $\mathrm{I}\left(\mathrm{R}_{1}\right.$ and $\mathrm{R}_{2} \mathrm{C}_{3}$ and $\left.\mathrm{R}_{6} \mathrm{C}_{2}\right)$, the female constructed cells or re-used the old ones, provisioned and oviposited in them. This female was classified as a foraging/egg laying female (FELF). In types II $\left(\mathrm{R}_{1} \mathrm{C}_{1}, \mathrm{R}_{1} \mathrm{C}_{2}\right.$, and $\left.\mathrm{R}_{2} \mathrm{C}_{2}\right)$ and III $\left(\mathrm{R}_{2} \mathrm{C}_{1}, \mathrm{R}_{3} \mathrm{C}_{1}, \mathrm{R}_{4} \mathrm{C}_{1}, \mathrm{R}_{3} \mathrm{C}_{2}, \mathrm{R}_{4} \mathrm{C}_{2}\right.$, and $\left.\mathrm{R}_{5} \mathrm{C}_{2}\right)$, the females that participated in the association behaved in different ways. One or more than one female behaved like an FELF, while another one remained in the nest and oviposited in cells provisioned and oviposited in by the FELF, immediately after having performed oophagy. Based on these behaviors, this female was classified as the dominant female (DF), while the FELF was classified as a subordinate female (SF). In most of the reactivation processes $(\mathrm{N}=$ 7), the female that was dominant was always the oldest female of the association. However, in two cases it was impossible to determine if the female replacing the dominant female was really the oldest female of the association because some females had lost their marks.

Reactivation by more than one female in the absence of females that had participated in the previous reactivation $(\mathrm{N}=3)$ : these reactivations occurred during $\mathrm{R}_{1}$ of nests $\mathrm{C}_{1}$ and $\mathrm{C}_{2}$ (after these new nests had been set up in the laboratory) and during $\mathrm{R}_{2}$ of nest $\mathrm{C}_{2}$. Three and six females participated in $\mathrm{R}_{1} \mathrm{C}_{1}, \mathrm{R}_{1} \mathrm{C}_{2}$, and $\mathrm{R}_{2} \mathrm{C}_{2}$, respectively (Figure $1 \mathrm{~A}, \mathrm{~B}$ ). The $\mathrm{DF}$ of the $\mathrm{R}_{1} \mathrm{C}_{2}$ disappeared from the nest when she was 69 days old. In $\mathrm{R}_{2} \mathrm{C}_{2}$, before the female became dominant, she behaved as an FELF, provisioning and ovipositing in two cells. This female interrupted her provisioning activities and assumed the dominant position after a second female had remained in the nest (Figure 1B).
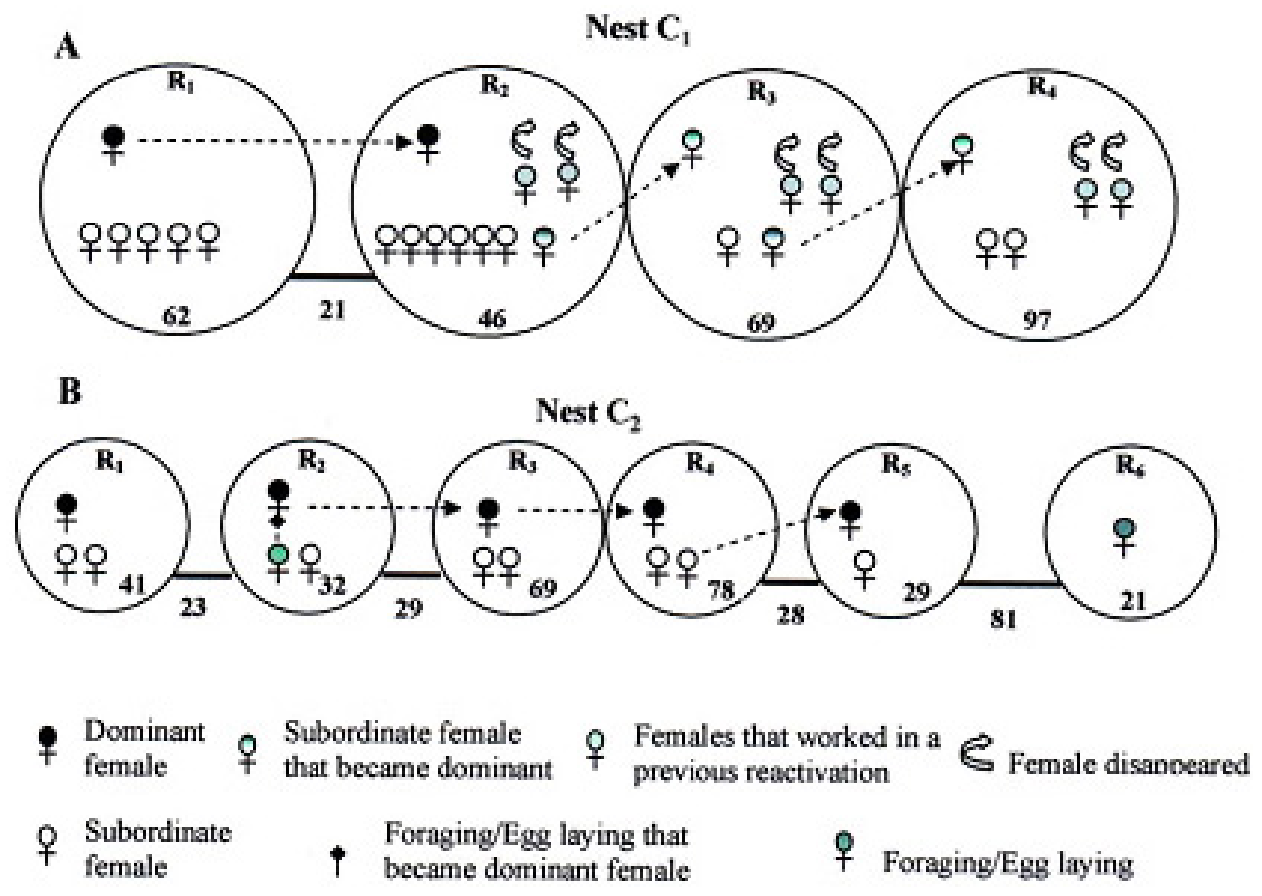

Figure 1. Schematic representation of reactivation processes observed in Euglossa fimbriata nests. Reactivation processes occurred in nests $C_{1}(A)$ and $C_{2}(B) . R_{1}-R_{6}=$ reactivation processes; number inside the circles = duration (in days) of each reactivation process; number between the circles = duration (in days) of the periods of inactivity between two successive reactivation process. 
Reactivation by more than one female in the presence of females that had participated in the previous reactivation process $(\mathrm{N}=6)$ : these processes had the participation of one $\left(\mathrm{R}_{5} \mathrm{C}_{2}\right)$, two $\left(\mathrm{R}_{3} \mathrm{C}_{1}, \mathrm{R}_{4} \mathrm{C}_{1}, \mathrm{R}_{3} \mathrm{C}_{2}, \mathrm{R}_{4} \mathrm{C}_{2}\right)$, or seven $\left(\mathrm{R}_{2} \mathrm{C}_{1}\right)$ reactivating females that remained in the nest after emerging.

The $R_{2}$ of the nest $C_{1}$ began in the presence of the DF of the $R_{1}$ and two SFs that had worked in the $\mathrm{R}_{1}$ and after finishing their reproductive activities remained in the nest (Figure 1A). These two SFs disappeared from the nest some days after the $\mathrm{R}_{2}$ had begun. The DF was found dead 24 days after the $\mathrm{R}_{2}$ had begun and when she was 111 days old. One of the SFs that had already finished her reproductive activities assumed the dominance. This reactivation began with a matrifilial association and finished with a sororal association. Two SFs participated in the $\mathrm{R}_{3}$. The oldest was a DF's sister while the other was her daughter. The DF disappeared from the nest 45 days after the reactivation had begun and when she was at least 78 days old. The disappearance of the DF occurred after the SFs had oviposited in six cells. Of these six cells, five had been oviposited in by DF's sister and one by her daughter. The DF's sister became the new DF of the nest and maintained this status during the $\mathrm{R}_{4}$. In this reactivation, one of the SF was DF's niece while the other was her daughter. The observations were interrupted during this reactivation. As was observed in the $\mathrm{R}_{2}$, the third and fourth reactivations of the nest $\mathrm{C}_{1}$ began in the presence of two SFs that had participated in the previous process, and in both cases they disappeared from the nest after the new reactivations had begun (Figure 1A).

A matrifilial association occurred during $\mathrm{R}_{3}$ and $\mathrm{R}_{4}$ of nest $\mathrm{C}_{2}$ (mother, the $\mathrm{DF}$, and two daughters, the SFs). The mother had already participated in $\mathrm{R}_{2}$ as DF in the sororal association observed in that reactivation. She disappeared from the nest during $\mathrm{R}_{4}$, when she was 196 days old, after the SFs had each oviposited in one or two cells. In the absence of the DF and of the oldest SF that had disappeared before the DF, the youngest SF continued working in the nest and oviposited in other two cells as an FELF. After that she interrupted her reproductive activities, remained in the nest and participated in the $\mathrm{R}_{5}$, behaving as DF. This female disappeared from the nest when she was 143 days old. The SF of the $\mathrm{R}_{5}$ was DF's sister (Figure 1B).

\section{Behavior performed by subordinate females}

\section{Re-use and construction of cells}

During a reactivation process, the SF may built new cells or re-use the old ones utilizing the resin available in the nest or resin collected in the field by herself or by another SF, if present. To re-use a cell, the female cleaned the cell from which the adult had emerged, after that she incremented the walls by successive additions of resin and further manipulation; they lined the inner walls with resin. Of the 12 reactivation processes observed, in six reactivations $\left(\mathrm{R}_{2}, \mathrm{R}_{3}, \mathrm{R}_{4}\right.$, and $\mathrm{R}_{6} / \mathrm{C}_{2}$ and $\mathrm{R}_{1}$ and $\left.\mathrm{R}_{2} / \mathrm{C}_{3}\right)$ no cell was built, in five $\left(\mathrm{R}_{2}, \mathrm{R}_{3}\right.$ and $\mathrm{R}_{4} / \mathrm{C}_{1}$ and $\mathrm{R}_{1}$ and $\mathrm{R}_{5} / \mathrm{C}_{2}$ ) the number of re-used cells was greater than that of constructed cells, and in only one process $\left(\mathrm{R}_{1} / \mathrm{C}_{1}\right)$ the number of constructed cells was greater than that of re-used cells. In only two reactivations $\left(\mathrm{R}_{1} / \mathrm{C}_{1}\right.$ and $\left.\mathrm{R}_{1} / \mathrm{C}_{2}\right)$, the number of cells available for re-use was lower than the number of cells oviposited in during reactivation.

Resin-collecting trips $(\mathrm{N}=38)$ were made from 10:00 to 18:00 $\mathrm{h}$ but they were 
more frequent between 13:00 and 17:00 $\mathrm{h}(\mathrm{N}=34$; Figure 2). The resin loads brought into the nest were deposited on the floor of the nest near the cells, at the nest entrance or on the cells themselves. Irrespective of the number of females participating in the reactivation process, each cell was always built by a single female. Cell construction consisted of numerous trips to collect the deposited resin or the resin from the old cells, transportation to where the new cell was being built, and construction of the cell. The female started provisioning when approximately $1 / 4$ of the cell had been completed.

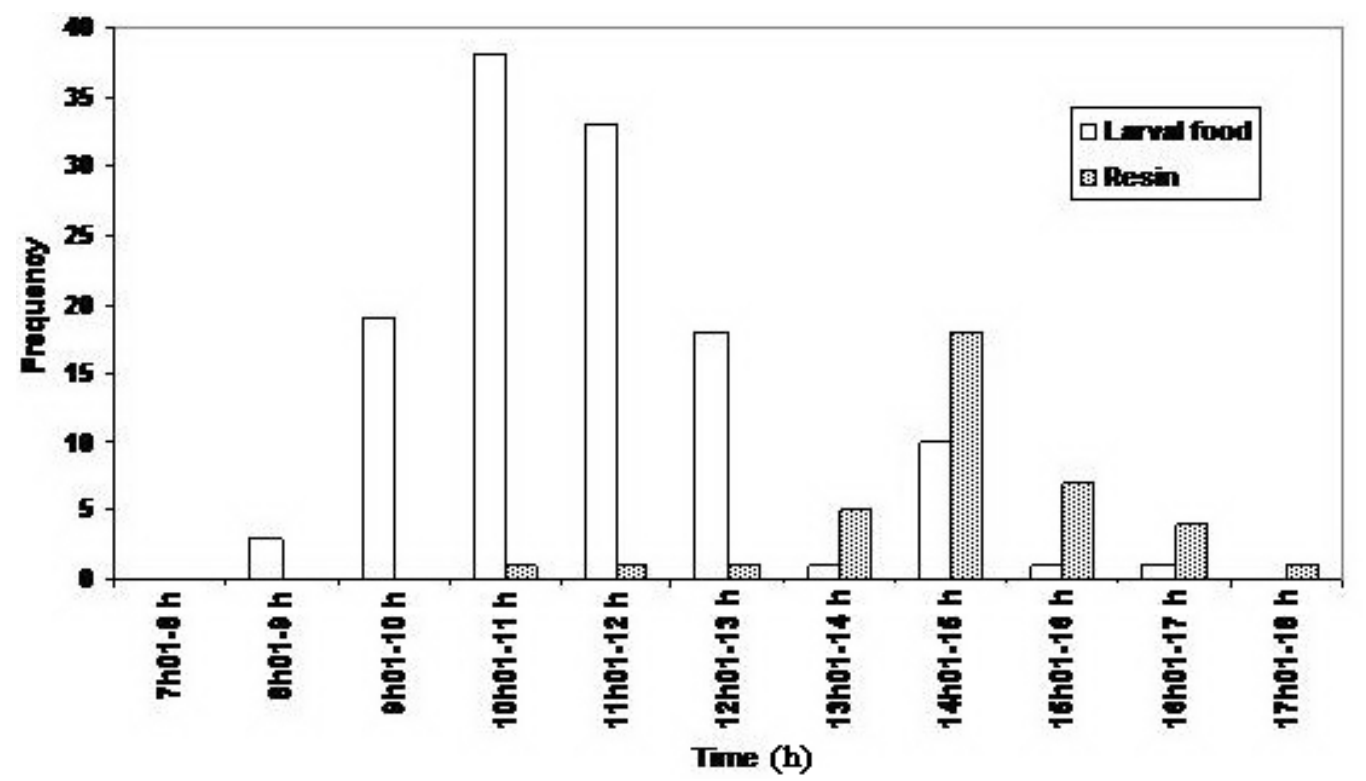

Figure 2. Time of collection of larval food and resin by subordinate females of Euglossa fimbriata.

\section{Cell provisioning}

Each SF provisioned her own cell. The SF began the larval-food-collecting trips when they were four $(\mathrm{N}=2)$, five $(\mathrm{N}=1)$ or $\operatorname{six}(\mathrm{N}=2)$ days old. Most trips $(\mathrm{N}=124)$ occurred between 10:00 and 12:00 h ( $\mathrm{N}=71)$ (Figure 2) and lasted from 19.7 to 55.97 min (mean $=33.90$ $\pm 7.91 \mathrm{~min} ; \mathrm{N}=40$ ). When returning from a trip, the female entered the nest, walked to her cell, inspected it by introducing her head, and then introduced her abdomen into the cell and discharged the larval food. Food discharge was usually followed by rotational activity, during which the female turned clockwise and/or counterclockwise, one or more times. The total time from abdomen insertion into the cell to abdomen withdrawal ranged from 14 to $78 \mathrm{~s}$ (mean $=$ $35.18 \pm 11.62 \mathrm{~s} ; \mathrm{N}=100)$, with the highest frequency $(\mathrm{N}=74)$ occurring between 21 and 40 $\mathrm{s}$. The time spent inside the nest between provisioning trips ranged from 26 to $478 \mathrm{~s}$ (mean $=$ $96.39 \pm 84.66 \mathrm{~s} ; \mathrm{N}=92)$, but it was more frequent between 41 and $70 \mathrm{~s}$.

The duration of cell provisioning $(\mathrm{N}=71)$ ranged from two to five days, with the most frequent duration of provisioning being two $(\mathrm{N}=28)$ and three days $(\mathrm{N}=33)$. 


\section{Oviposition and cell operculation}

The ovipositions were always preceded by the construction of the cell collar. During this activity, the female added resin to the walls of the cell, increasing the height by approximately $2 \mathrm{~mm}(\mathrm{~N}$ $=21$ ). The time spent by the female on this activity ranged from 783 to $4091 \mathrm{~s}$ (mean $=1837 \pm 960$ $\mathrm{s} ; \mathrm{N}=16$ ). After finishing the collar, the female introduced her abdomen into the cell and oviposited. The time spent in oviposition ranged from 32 to $88 \mathrm{~s}$ (mean $=69.4 \pm 12.6 \mathrm{~s} ; \mathrm{N}=21)$. After oviposition, the female began operculation. This process was divided into two phases. In the first phase, the female, with her abdomen still within the cell, rotated her body and began to close the orifice by bending the collar with her mandibles and forelegs, while withdrawing the abdomen from the cell.

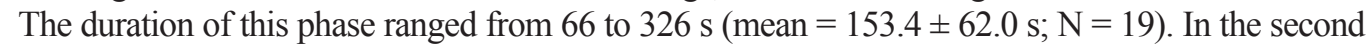
phase, the female with her body outside of the cell, finished the closure by pressing the collar with her mandibles only. Then, the female left the cell many times to collect resin from adjacent cells and placed it on the apical region of the cell. The time spent in this phase ranged from 79 to $575 \mathrm{~s}$ (mean $=277.8 \pm 177.1 \mathrm{~s} ; \mathrm{N}=17)$. All ovipositions $(\mathrm{N}=21)$ were made in the afternoon.

The number of cells oviposited by each SF $(\mathrm{N}=23)$ ranged from one to 14 cells, and it was significantly correlated $(\mathrm{r}=0.91 ; \mathrm{P}<0.05)$ with her period of activity, which ranged from 2 to 48 days $(\mathrm{N}=23)$. The total time of residence in the nest ranged from 6 to 77 days.

Agonistic interaction among SF(s) was not observed, except when one of them approximated another while it was working in its own cell.

\section{Behaviors performed by dominant females}

The DF rarely leaves the nest; it becomes the main guard bee, usually remaining near the nest entrance while the SFs are foraging. When an SF returns to her nest with larval food and walks to the cell that she is provisioning, the DF withdraws from the nest entrance and walks towards the cell cluster where the SF is discharging the larval food. The DF stays some centimeters away and watches the SF. After the SF discharging the larval food and going to the field again, the DF inspects the cell and after that walks toward to nest entrance. On some occasions, when the SF delayed going to the field after discharging the larval food or the load of resin brought to the nest, the DF advanced towards her, touched the SF with her antennae or her head or tried to bite her hind legs, forcing SF out of the nest.

When the SF began the construction of the cell collar, the DF stayed on the cell cluster, walking from one side to the other, observing the SF. Whenever the DF arrived very near the $\mathrm{SF}$, the SF interrupted her activities and restarted only after the DF was driven away. Among the 21 observed processes, in 16 of them the SFs had their activity momentarily interrupted due to aggression by the dominant female, or simply because she came too close. After ovipositing and operculating the cell, the SF may go out to the field or begin another activity inside the nest. From this moment, the DF becomes agitated, walking quickly on the cell cluster, stopping on the cell oviposited in by the SF, and opening it. The DF then performs oophagy, oviposits, and re-caps the cell. In six of 21 observed processes, the SF was attacked by the DF before the cell had been completely closed. In these cases, the DF finished operculation of the cell, and later on she re-opened the cell, ate the subordinate's egg, and oviposited in the cell. Whenever an SF remained on the nest because it was building a cell or because she had finished her field activities, or during the night, the DF remained on the cell cluster and prevented the subordinated female 
from staying there. The SF never behaved aggressively toward the DF or to other SFs.

Opening of the cell by DF occurred in the presence or absence of the SF, and the time spent by DF on this activity ranged from 65 to $120 \mathrm{~s}$ (mean $=88.8 \pm 26.9 \mathrm{~s} ; \mathrm{N}=8$ ). After opening the cell, the DF performs the oophagy, which lasts 55 to $169 \mathrm{~s}$ (mean $=97.1 \pm 31.4 \mathrm{~s} ; \mathrm{N}=$ 8). The interval between oviposition by SF and oophagy by DF ranged from 28 to $201 \mathrm{~min}(\mathrm{~N}=$ 21). Before starting oviposition, the DF placed her head inside the cell and expanded the opening by performing rotating movements. Then, she oviposits, which lasts 43 to $90 \mathrm{~s}$ (mean $=64.9$ $\pm 17.4 \mathrm{~s} ; \mathrm{N}=10)$; this time was not significantly different from that observed for $\mathrm{SFs}(\mathrm{Z}=-0.95$; $\mathrm{P}>0.05$, Mann-Whitney test). After the oviposition finished, the DF started the operculation process, following the same behavioral sequence displayed by SF. The time spent by DF in each phase of the operculation process (phase I = range: 47 to $102 \mathrm{~s}$; mean $=80.4 \pm 20.2 \mathrm{~s}$; phase II = range: 67 to $237 \mathrm{~s}$; mean $=123.2 \pm 54.2 \mathrm{~s} ; \mathrm{N}=10$ ) was significantly shorter than that spent by $\mathrm{SF}(\mathrm{Z}=3.37 ; \mathrm{P}<0.05$ and $\mathrm{Z}=2.58 ; \mathrm{P}<0.05$, respectively, Mann-Whitney tests).

Irrespective of the behavior displayed, all females dissected $(\mathrm{N}=7)$ had been inseminated.

\section{Number of cells built during a reactivation process}

The total number of cells oviposited during a reactivation was significantly correlated $(\mathrm{r}=$ $0.69 ; \mathrm{P}<0.05 ; \mathrm{N}=12$ ) with the number of females (FELF or SF) working on each of them (Table 1). However, irrespective of the number of females (FELF or SF) in each reactivation, the number of cells per female was not significantly different $(\mathrm{H}=6.35 ; \mathrm{P}>0.05$, Kruskal-Wallis test). Similarly, the per-capita brood production was not significantly correlated $(\mathrm{r}=0.19 ; \mathrm{P}>0.05 ; \mathrm{N}=12)$ with the number of females (FELF and DF $+\mathrm{SF}$ ) participating in the reactivation process.

\begin{tabular}{|c|c|c|c|c|}
\hline \multirow[t]{2}{*}{ Nest code } & \multirow{2}{*}{$\begin{array}{l}\text { Number of females that } \\
\text { participated in each } \\
\text { reactivation }\end{array}$} & \multirow{2}{*}{$\begin{array}{l}\text { Total cells } \\
\text { oviposited }\end{array}$} & \multicolumn{2}{|c|}{ Emergence observed $^{1}$} \\
\hline & & & Male & Female \\
\hline Nest $C_{1}$ original cluster & & 14 & 2 & 8 \\
\hline $\mathrm{R}_{1} / \mathrm{C}_{1}$ & $\mathrm{DF}+5 \mathrm{SF}$ & 49 & 36 & 9 \\
\hline $\mathrm{R}_{2} / \mathrm{C}_{1}$ & $\mathrm{DF}+7 \mathrm{SF}$ & 20 & 8 & 3 \\
\hline $\mathrm{R}_{3} / \mathrm{C}_{1}$ & $\mathrm{DF}+2 \mathrm{SF}$ & 14 & 4 & 4 \\
\hline $\mathrm{R}_{4}^{3} / \mathrm{C}_{1}$ & $\mathrm{DF}+2 \mathrm{SF}$ & 9 & \multicolumn{2}{|c|}{ Observation interrupted } \\
\hline Nest $\mathrm{C}_{2}$ original cluster & & 14 & 7 & 3 \\
\hline $\mathrm{R}_{1} / \mathrm{C}_{2}$ & $\mathrm{DF}+2 \mathrm{SF}$ & 18 & 10 & 8 \\
\hline $\mathrm{R}_{2} / \mathrm{C}_{2}^{2}$ & $\mathrm{DF}+2 \mathrm{SF}$ & 3 & 1 & 2 \\
\hline $\mathrm{R}_{3}^{2} / \mathrm{C}_{2}^{2}$ & $\mathrm{DF}+2 \mathrm{SF}$ & 11 & 0 & 5 \\
\hline $\mathrm{R}_{4} / \mathrm{C}_{2}$ & $\mathrm{DF}+2 \mathrm{SF}$ & $6^{2}$ & 0 & 2 \\
\hline $\mathrm{R}_{5} / \mathrm{C}_{2}^{2}$ & $\mathrm{DF}+1 \mathrm{SF}$ & 5 & 1 & 3 \\
\hline $\mathrm{R}_{6} / \mathrm{C}_{2}$ & 1 FELF & 1 & 0 & 1 \\
\hline Nest $\mathrm{C}_{3}$ original cluster & & 11 & 4 & 3 \\
\hline $\mathrm{R}_{1} / \mathrm{C}_{3}$ & 1 FELF & 8 & 2 & 6 \\
\hline $\mathrm{R}_{2} / \mathrm{C}_{3}$ & 1 FELF & 1 & 0 & 0 \\
\hline
\end{tabular}

$\mathrm{DF}=$ dominant female; $\mathrm{SF}=$ subordinate female $\mathrm{FELF}=$ foraging/egg laying female. ${ }^{1} \mathrm{~A}$ difference between the total number of cells oviposited and the observed emergence of bees occurred because some individuals emerged while the nests were not being observed and did not return to the nests. ${ }^{2}$ No bee emerged from three cells. 


\section{The egg-to-adult periods}

In reactivations that occurred during the hot and rainy season (September-April) no significant difference was found between the egg-to-adult periods for males (range: 45-58 days; mean $=49.91 \pm 3.05$ days; $\mathrm{N}=43$ ) as compared to females (range: $44-65$ days; mean $=$ $51.71 \pm 5.28$ days; $\mathrm{N}=28)(\mathrm{Z}=-1.52 ; \mathrm{P}>0.05$, Mann-Whitney test $)$. The egg-to-adult periods for males produced during the cool and dry season (May-August) ranged from 55 to 116 days; mean $=74.83 \pm 30.76$ days; $\mathrm{N}=6$ ) while for the only female that emerged from an egg produced in that season the egg-to-adult period was 113 days. The times of development found for males in each season were significantly different $(Z=-3.630 ; P<0.05$, Mann-Whitney test).

\section{DISCUSSION}

\section{Nesting biology}

Nesting in preexisting cavities by E. fimbriata, as we found in this study, is a characteristic shown by most Euglossa species (Zucchi et al., 1969a; Garófalo, 1992; Garófalo et al., 1993, 1998; Augusto and Garófalo, 2004, 2007), except those that build aerial nests, such as $E$. hyacinthina, E. championi (Eberhard, 1988) and E. turbinifex (Dressler, 1982; Young, 1985).

In general, the architecture of the nests that we studied was similar to that described for several other species: the nest entrance in a resinous wall constructed in the cavity entrance, absence of an inner wall coating of the cavity, sealing of cracks inside the cavity with resin, brood cells built of resin and in close contact (Zucchi et al., 1969a; Garófalo, 1992; Garófalo et al., 1993, 1998; Augusto and Garófalo, 2004, 2007). Similarly, the behavioral patterns displayed by E. fimbriata females during cell construction, provisioning, oviposition, operculation, and the tendency to re-use the old cells resembled those described for $E$. cordata (Garófalo CA, unpublished results) and E. townsendi (Augusto and Garófalo, 2004). On the other hand, in contrast to what was observed in E. townsendi, E. fimbriata does not remove the resin from cells after cocoons have been spun by the larvae to utilize it in the construction of a new cell. This behavior could be one of the factors responsible for the larger quantities of available resin in the nests of E. fimbriata and E. cordata than in nests of E. townsendi.

We found that the egg-to-adult period was similar for males and females of E. fimbriata, and it was influenced by climatic conditions, as also reported by Garófalo (1985) for E. cordata, Ramírez-Arriaga et al. (1996) for E. atroveneta, Augusto and Garófalo (2004) for E. townsendi, Garófalo et al. (1993) for E. pleosticta and E. truncata, Santos and Garófalo (1994) for Eulaema nigrita, and Garófalo and Rozen Jr. (2001) for the cleptoparasite Exaerete smaragdina.

The finding of more than one female and a large number of cells in the two nests of $E$. fimbriata that we studied, together with subsequent observations, indicate that both nests had been reactivated one or more times before being found. Reactivation of the nest by succeeding generations has been reported for all the species of Euglossa that had the development of their nests studied through direct observations, including E. cordata (Garófalo, 1985; Augusto and Garófalo, 1994), E. atroveneta (Ramírez-Arriaga et al., 1996), E. annectans (Garófalo et al., 1998), E. hyacinthina (Soucy et al., 2003), and E. townsendi (Augusto and Garófalo, 2004). Similarly, reactivation of the nest was also suggested for species whose nests were collected and analyzed soon after being found, such as E. ignita (Dodson, 1966), E. imperialis (Rob- 
erts and Dodson, 1967), E. melanotricha (Sakagami et al., 1967), E. intersecta (Zucchi et al., 1969b), and E. championi and E. hyacinthina (Eberhard, 1988). The occurrence of reactivations and multi-female nests in all those species suggest that such characteristics occur at a higher frequency than that usually suspected.

The number of females participating in each reactivation was variable, and the number of cells oviposited increased with the number of SF working in each reactivation process. These results are typical traits of colonies in which the females show independent reproductive activities, as observed for forager/egg-laying females of E. townsendi (Augusto and Garófalo, 2004) and observed for communal species, such as Pseudagapostemon divaricatus (Halictidae) (Michener, 1964), Lasioglossum hemichalceum (Halictidae) (Kukuk et al., 1998), E. nigrita (Santos and Garófalo, 1994), and E. hyacinthina (Soucy et al., 2003). As in P. divaricatus, Ceratina japonica (Apidae) (Sakagami and Maeta, 1985), E. nigrita, and E. townsendi, the productivity per FELF or SF of E. fimbriata remained constant, irrespective of the number of females participating in the reactivation processes.

\section{Social structure and the origin of eusociality}

As observed in the multifemale colonies of E. cordata (Garófalo, 1985; Augusto and Garófalo, 1994) and E. townsendi (Augusto and Garófalo, 2004), in E. fimbriata all adult females are also totipotent. As a result of this characteristic, the tasks that each female exercises depend on the social context of the nest in which a young female emerges, as also observed for some halictid species (Schwarz et al., 2007). Thus, as we observed, when a matrifilial or sororal association is originated, the mother, in the first case, and the first female to remain in the nest, in the second case, becomes behaviorally and reproductively dominant and the other females become subordinate. Thus, in both associations the oldest female becomes the dominant female, suggesting that age is a major proximate determinant of task allocation in E. fimbriata. The replacement of the dominant by the oldest subordinate female in the nest reinforces the idea of an age-based dominance hierarchy. While such a model of dominance hierarchy is similar to that reported by Garófalo (1985) for E. cordata, it differs substantially from the behavior of E. townsendi, as discussed by Augusto and Garófalo (2004). Age-based and order-of-adult-eclosion hierarchies have been reported for some bee and wasp species (Schwarz and Woods, 1994; Tsuji and Tsuji, 2005; Bridge and Field, 2007). On the basis of an inclusive fitness model, Tsuji and Tsuji (2005) suggested two patterns of dominance based on the expected life span of the group relative to the life span of the individuals. They suggested that when the expected colony life is far longer than the individual's life, replacement of the dominant individual will regularly occur by a young individual and, when the expected colony life is shorter than the individual's potential longevity, the oldest female should dominate over the others. The sequence and duration of the reactivation processes in both our nests of E. fimbriata, the time of permanence in the nests of dominant and subordinate females and the observed replacement processes of the dominant females contradict the prediction of Tsuji and Tsuji (2005). Similarly, the results reported by Garófalo (1985) and Augusto SC (unpublished results) for E. cordata, and by Bridge and Field (2007) for Liostenogaster flavolineata, a primitively eusocial hover wasp, also contradict that prediction. However, as noted by Tsuji and Tsuji (2005), there are exceptions to their prediction.

Although all females sharing a nest of $E$. fimbriata have developed ovaries, have been inseminated, and oviposit, as also observed in E. cordata (Garófalo CA, unpublished results) 
and E. townsendi (Augusto and Garófalo 2004), the production of offspring is monopolized by the dominant female, which, after oophagy, replaces the eggs laid by the subordinate females with her own. Under this condition, in all associations formed during the reactivation processes in E. fimbriata nests, as also observed in E. cordata (Garófalo, 1985; Augusto and Garófalo, 1994), the reproductive skew is complete. Therefore, to allow the SFs to oviposit and later replace their eggs would be, in these cases, a prudent selfish strategy to avoid group dispersal or lethal fighting, as predicted by the transactional models of reproductive skew (Reeve and Keller, 2001). Nevertheless, as we observed in this study, and as reported by Garófalo (1985) for E. cordata, complete skew occurred independently of genetic relatedness between the dominant and the subordinate, contradicting the predictions of the transactional models. On the other hand, as predicted by the transactional model of within-group conflict, the higher skew observed in colonies of $E$. fimbriata compared to colonies of $E$. townsendi may be a consequence of the aggressive behavior of the DF in E. fimbriata towards SF and the absence of within-group aggression in E. townsendi. As in E. cordata, the only significant advantage for subordinate females of E. fimbriata would be their potential to replace the dominant female after she disappears or dies, as observed during the reactivation processes.

The behaviors displayed by DFs of E. fimbriata and E. cordata and by egg-laying females of E. townsendi are characteristic of brood parasitism (Field, 1992) and fit the parental parasitism hypothesis put forward by Charnov (1978) and Stubblefield and Charnov (1986): 1. the mother would be under strong selection to parasitize her daughters if she had the opportunity to do so; this occurs during the reactivation processes; 2 . the mother gains a substantial selective advantage if she diverts resources from the production of grand-offspring to the production of additional offspring; the mother can do this by replacing her daughter's eggs with her own; 3 . by eating her daughter's eggs the mother gains high-quality nutrients, which permit her to increase her longevity and fecundity, as observed for DFs, exploiting the advantages of parasitism. According to Charnov (1978), if parental parasitism is indeed the first step towards eusocial behavior, it immediately provides "queen-like" behavior for the mother, and selection would favor her giving up those duties, which probably carry a considerable mortality risk. Thus, she should give up provisioning cells to remain at the nest site and parasitize her daughter cells. Our observations in this study and those reported by Garófalo (1985) and Augusto and Garófalo (1994), for E. cordata, and Augusto and Garófalo (2004), for $E$. townsendi, show that such species have bionomical traits that resemble the conditions suggested as precursors of the origin of eusociality in the Apinae.

\section{ACKNOWLEDGMENTS}

We dedicate this paper to Dr. Warwick E. Kerr, in recognition of his studies on bees. Research supported by CNPq. We are grateful to J.C. Serrano for technical help. S.C. Augusto received a grant from CAPES.

\section{REFERENCES}

\footnotetext{
Augusto SC and Garófalo CA (1994). Comportamento das Fêmeas nas Associações Formadas em Ninhos de Euglossa cordata (Hymenoptera; Apidae; Euglossini). In: Anais do I Encontro sobre Abelhas, Ribeirão Preto, $171-181$. Augusto SC and Garófalo CA (2004). Nesting biology and social structure of Euglossa (Euglossa) townsendi Cockerell
} 
(Hymenoptera, Apidae, Euglossini). Insectes Soc. 51: 400-409.

Augusto SC and Garófalo CA (2007). Nesting of Euglossa (Euglossa) melanotricha Moure (Hymenoptera: Apidae) in the ground of cerrado. Neotrop. Entomol. 36: 153-156.

Bridge C and Field J (2007). Queuing for dominance: gerontocracy and queue-jumping in the hover wasp Liostenogaster flavolineata. Behav. Ecol. Sociobiol. 61: 1253-1259.

Cameron SA (2004). Phylogeny and biology of Neotropical orchid bees (Euglossini). Annu. Rev. Entomol. 49: 377-404.

Cameron SA and Ramírez S (2001). Nest architecture and nesting ecology of the orchid bee Eulaema meriana (Hymenoptera: Apinae: Euglossini). J. Kans. Entomol. Soc. 74: 142-165.

Charnov EL (1978). Evolution of eusocial behavior: offspring choice or parental parasitism? J. Theor. Biol. 75: 451-465.

Dodson CH (1966). Ethology of some bees of the tribe Euglossini (Hymenoptera: Apidae). J. Kans. Entomol. Soc. 39: 607-629.

Dressler RL (1982). Biology of orchid bees (Euglossini). Ann. Rev. Ecol. Syst. 13: 373-394.

Eberhard WG (1988). Group nesting in two species of Euglossa bees (Hymenoptera: Apidae). J. Kans. Entomol. Soc. 61: 406-411.

Field J (1992). Intraspecific parasitism as an alternative reproductive tactic in nest-building wasps and bees. Biol. Rev. 67: 79-126.

Garófalo CA (1985). Social structure of Euglossa cordata nests (Hymenoptera: Apidae: Euglossini). Entomol. Gen. 11: 77-83.

Garófalo CA (1992). Comportamento de nidificação e estrutura de ninhos de Euglossa cordata (Hymenoptera: Apidae: Euglossini). Rev. Bras. Biol. 52: 187-198.

Garófalo CA and Rozen JG Jr (2001). Parasitic behavior of Exaerete smaragdina with descriptions of its mature oocyte and larval instars (Hymenoptera, Apidae, Euglossini). Am. Mus. Novitates 3349: 1-26.

Garófalo CA, Camilo E and Serrano JC (1993). Utilization of trap nest by Euglossini species (Hymenoptera: Apidae). Rev. Bras. Biol. 53: 177-187.

Garófalo CA, Camilo E, Augusto SC, Jesus BMV, et al. (1998). Nest structure and communal nesting in Euglossa (Glossura) annectans Dressler (Hymenoptera, Apidae, Euglossini). Rev. Bras. Zool. 15: 589-596.

Kukuk PF, Ward SA and Jozwiak A (1998). Mutualistic benefits generate an unequal distribution of risky activities among unrelated group members. Naturwissenschaften 85: 445-449.

Michener CD (1964). Reproductive efficiency in relation to colony size in hymenopterous societies. Insectes Soc. 11: 317-341.

Parra-H A, Ospina-Torres A and Ramírez S (2006). Euglossa natesi n. sp., a new species of orchid bee from the Chocó region of Colombia and Ecuador (Hymenoptera: Apidae). Zootaxa 129: 29-36.

Pereira-Martins SR and Kerr WE (1991). Biologia de Eulaema nigrita. 3. Inferências evolutivas. Pap. Avuls. Zool. 37: 584-585.

Ramírez-Arriaga E, Cuadriello-Aguilar JI and Hernández EM (1996). Nest structure and parasite of Euglossa atroveneta Dressler (Apidae: Bombinae: Euglossini) at Unión Juárez, Chiapas, México. J. Kans. Entomol. Soc. 69: 144-152.

Rebêlo JMM (2001). História Natural das Euglossíneas. As abelhas das orquídeas. Lithograf Editora, São Luís.

Rebêlo JMM and Silva FS (1999). Distribution of Euglossini bees (Hymenoptera: Apidae) in Maranhão State, Brazil. An. Soc. Entomol. Bras. 28: 389-401.

Reeve HK and Keller L (2001). Tests of reproductive-skew models in social insects. Annu. Rev. Entomol. 46: 347-385.

Roberts RB and Dodson CH (1967). Nesting biology of two communal bees, Euglossa imperialis and Euglossa ignita (Hymenoptera: Apidae) including description of larvae. Ann. Entomol. Soc. Am. 60: 1007-1014.

Sakagami SF and Maeta Y (1985). Multifemale nests and rudimentary castes in the normally solitary bee Ceratina japonica (Hymenoptera, Xylocopinae). J. Kans. Entomol. Soc. 57: 639-656.

Sakagami SF, Laroca S and Moure JS (1967). Two Brazilian apid nests worth recording in a reference to comparative bee sociology with description of Euglossa melanotricha Moure sp.n. (Hymenoptera: Apidae: Euglossini). Annot. Zool. Jpn. 40: 45-50.

Santos ML and Garófalo CA (1994). Nesting biology and nest re-use of Eulaema nigrita (Hymenoptera: Apidae, Euglossini). Insectes Soc. 41: 99-110.

Schwarz MP and Woods RE (1994). Order of adult eclosion is a major determinant of reproductive dominance in the allodapine bee Exoneura bicolor. Anim. Behav. 47: 373-378.

Schwarz MP, Richards MH and Danforth BN (2007). Changing paradigms in insect social evolution: insights from halictine and allodapine bees. Annu. Rev. Entomol. 52: 127-150.

Sofia SH and Suzuki KM (2004). Communities of Euglossini males (Hymenoptera: Apidae) in forest fragments from southern Brazil. Neotrop. Entomol. 33: 693-702.

Soucy SL, Giray T and Roubik DW (2003). Solitary and group nesting in the orchid bee Euglossa hyacinthina 
(Hymenoptera, Apidae). Insectes Soc. 50: 248-255.

Stubblefield JW and Charnov EL (1986). Some conceptual issues in the origin of eusociality. Heredity 57: 181-187.

Tsuji K and Tsuji N (2005). Why is dominance hierarchy age-related in social insects? The relative longevity hypothesis. Behav. Ecol. Sociobiol. 58: 517-526.

Young AM (1985). Notes on the nest structure and emergence of Euglossa turbinifex Dressler (Hymenoptera; Apidae; Euglossini) in Costa Rica. J. Kans. Entomol. Soc. 58: 538-543.

Zucchi R, Sakagami SF and Camargo JMF (1969a). Biological observations on a tropical parasocial bee, Eulaema nigrita, with a review on the biology of Euglossinae (Hymenoptera, Apidae). A comparative study. J. Fac. Sci. Hokkaido Univ. Series IV, Zool. 17: 271-380.

Zucchi R, Oliveira BL and Camargo JMF (1969b). Notas bionômicas sobre Euglossa (Glossura) intersecta Latreille 1838 e descrição de suas larvas e pupas (Euglossini, Apidae). Bol. Univ. Fed. Paraná, Zool. 3: 203-224. 